\title{
Eat the Rich: Pandemic Horror Cinema
}

Johan Höglund

\section{(2) OpenEdition \\ Journals}

Electronic version

URL: http://journals.openedition.org/transtexts/706

DOI: $10.4000 /$ transtexts.706

ISSN: 2105-2549

Publisher

Gregory B. Lee

\section{Electronic reference}

Johan Höglund, « Eat the Rich: Pandemic Horror Cinema », Transtext(e)s Transcultures 跨文本跨文化

[Online], 12 | 2017, Online since 09 July 2018, connection on 20 April 2019. URL : http://

journals.openedition.org/transtexts/706 ; DOI : 10.4000/transtexts.706

This text was automatically generated on 20 April 2019.

(c) Tous droits réservés 


\title{
Eat the Rich: Pandemic Horror Cinema
}

\author{
Johan Höglund
}

"When the people shall have nothing more to eat, they will eat the rich"

Adophe Thiers, citing Jean-Jacques Rousseau ${ }^{1}$

1 In South Korean film Train to Busan (2016), a hardworking, single and largely absent father and his young daughter board a high-speed train heading from the Seoul suburb Gwangmyeong to Busan. They are accompanied by a variety of other characters, a highschool baseball team and their one cheerleader, a couple of elderly ladies, a pregnant young woman and her combative and protective partner, and an egotistical senior manager. Except for a tramp who has climbed aboard and who hides in the bathroom, inexplicably frightened, all are solidly middle class.

2 As the train begins to pull out of the station, a young woman boards unseen. She has evidently been hurt. She has problems standing up. Her left leg is turning a strange white colour while the veins stand out, dark blue against the skin. Shortly after the departure, she falls over and has a seizure. Another young woman, a conductor on the train, rushes over to help but can offer little assistance. The conductor turns her back on the shaking body of the woman and attempts to use an uncooperative walkie-talkie to bring the sudden emergency to the attention of her fellow crew members. Her back turned, she does not see the seizures subside and the woman rising in a languid but threatening movement. It is not until the woman has fully regained her feet, standing at an oblique angel, that the conductor looks up to notice, first the unnatural posture, the discoloured skin, the milky white eyes, and, finally, the bared and snarling teeth that confronts her. In the next scene, the conductor is stumbling down the aisle with the young woman attached like a gigantic tick to her back, teeth clamped over the conductors exposed neck. The baseball team look on in abject confusion and horror. 


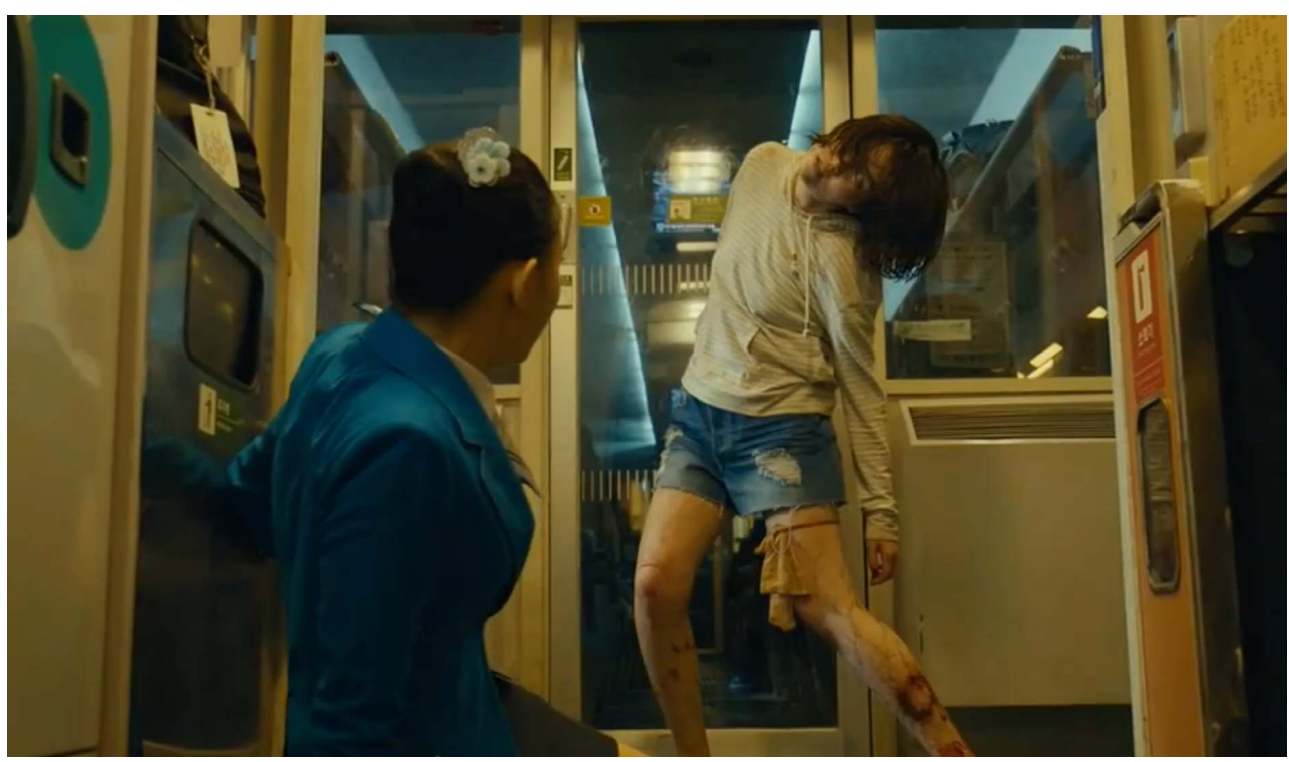

Caption: A young woman turned zombie rises from the floor to begin spreading the contagion she carries in Train to Busan.

3 This sequence is initially gothic and uncanny. The young woman, seemingly traumatized and hurt but potentially recognisable as self with her fashionably torn shorts and cotton hoodie, has transformed first into something clearly diseased and troubling, and then into a carnivorous, even cannibalistic agent of a doubly violent pandemic. What is disturbing to the viewer is certainly the violence she performs and spreads, but also the fact that the contagious agent is a young, diminutive, middle class, Asian woman. Her transformation into diseased Other challenges not only the dichotomy between health and illness, but also the stereotypical boundaries of gender, ethnicity and class. As the film plays out, this challenge collapses into a spectacle of violence and gore that causes the utter collapse of any recognizable social fabric, of modernity, even of the human as a meaningful species.

When trying to come to terms with the imagined diseases of the Other as represented within a wide transnational context, zombie cinema constitutes one of the most widely disseminated and multivocal expressions. In fact, most pandemic narratives with a wide distribution belong, like Train to Busan, to the genre of violent horror. This casts the pandemic in a very particular light. While actual pandemics can certainly impact society in drastic ways, and cause the demise of a vast number of people, the pandemic typically paralyses the victim. The pandemic, even when it moves quickly, still represents a form of slow violence, to borrow a term from Rob Nixon. ${ }^{2}$ While certainly not as slow as the environmental destruction that Nixon discusses in his seminal book, pandemics do not make a great deal of noise. They move silently over the globe, they slow their victims down rather than energize them, and, like gradual environmental catastrophe, they claim by far the most victims among the poor.

5 The point of pandemic horror cinema in general, and of the zombie film in particular, is that it makes a different understanding of the pandemic possible. With the aid of the horror genre, the pandemic is sped up and magnified so that its destructive capabilities become starkly visible. The slow violence of the viral pandemic here becomes hyper fast as undead carriers of zombie contagion run or stumble through chaotic streets in search of the still uninfected. This acceleration of pandemic violence enables the zombie film to 
invest the (imagined) disease it represents with specific political content and, in relation to this, to tie it to various types of Otherness.

6 As will be discussed below, this political content revolves around matters of religion, ethnicity, race and gender in general, but it also and importantly highlights the concept of class in transnational society. A point here is that while the microbes that spread illness (as well as assist human life in a number of positive ways as observed by Dipesh Chakrabarty (2017) $)^{3}$ does not recognize sexual, gendered, racial, ethnic or class-based borders, the impact of pandemics are typically strongly affected by class borders. Certain pandemics, like the Spanish Influenza of 1918, did kill more or less indiscriminately across these barriers. Yet, in most cases, the well-fed global middle class rarely suffers dramatically from pandemics today. Armed with all the medical benefits of modernity, including vaccinations, elaborate health care apparatuses, and wall-mounted dispensers of gelatinous disinfectant, the pandemic appears to the middle class as an anxiety and a reminder of their mortality, rather than as a palpable threat to their lives or dominant position. Several non-gothic or non-horror pandemic films, such as Wolfgang Petersen's Outbreak (1995), revolve around the possibility that an epidemic capable of disturbing the middle class might be let loose on the world, but never let this come to pass. In films such as this, brave white physicians penetrate into Ebola infested African communities to make sure the contagion never reach into European or US territories. The successful prevention of such transnational infection is the comforting closure of the film.

7 By contrast, global zombie cinema such as Train to Busan represents pandemics that invariably consume also the middle class. Thus, the present article discusses how most zombie films, again like Train to Busan, show middle-class protagonists succumbing to a pandemic disease, rising again in the shape of the utterly tattered poor, and joining the growing pack of similarly destitute zombies that roam a crumbling metropole. Whether cast as the fast and agile creature that has become more and more common in horror cinema in recent years, or as the traditional, lumbering being that still roams the streets in much popular culture, the zombie is essentially a person deprived of social status, of shelter, of food, of health care and of the infrastructure that makes middle class life possible. In short, the zombie is an iterant creature that no longer has access to the modernity that spawned it; that now stands outside modernity's comforting embrace, transformed into its violent and hungry Other. The zombie's abject poverty, I will argue, will remind the middle-class movie audience of other middle-class citizen deprived of his or her wealth by bad planning, drugs or simply the precariousness of the post $9 / 11$ economy, or equally of the migrant subaltern forced from his or her home by war and ethnic cleansing and now inhabiting street corners, railway stations, camps and parks in a comparatively affluent West.

8 With this in mind, this article argues that pandemic horror cinema facilitates an often eloquent conversation on the relation between the imagined diseases of the Other and modernity as an engine of middle-class preservation. To bring the different discursive strands of this conversation to light, this article first traces the tradition of the gothic and horror pandemic narrative from its nineteenth-century origins to the present moment in time when it has proliferated into a number of different nations, languages and ideological positions. The article then explores these positions in some detail through a discussion of a number of pandemic horror narratives, with a focus on the films Dawn of the Dead (2004), I am Legend (2007), World War Z (2013), and Train to Busan. Through the focus on how these narratives consider religion, race, ethnicity, and, in particular, class, 
in relation to pandemic disease, the article will describe how the pandemic horror cinema helps project different understandings of self and Other through the image of pandemic disease.

\section{The Anglo Pandemic Narrative}

9 The pandemic narrative has a very long history and has often accompanied, or followed in the wake of, actual pandemics. These narratives have always been deeply influenced by existing ideologies and prejudices, and helped to produce certain identity formations through the production or intensification of already existing types of Otherness. Thus, the plague known as the Black Death that struck the world in the $14^{\text {th }}$ century was, as discussed by David Nirenberg in Communities of Violence (1998), perceived a disease produced by, or because of, minority groups such as Jews or Muslims. ${ }^{4}$ In this way, the pandemic became a way to comprehend one's belonging to, or exclusion from, a religious, regional or national community. At the same time, by analogy, religious Otherness could be cast as in itself a form of disease or even pandemic. Understood in this way, the Black Death could be imagined as a kind of religious illness that those of weak faith could not resist. By the same analogy, non-normative religions could be imagined as diseases or infections that, if not contained, could bring great destruction.

The precursor to the modern zombie film makes this connection clear. In nineteenthcentury gothic fiction such as Sheridan Le Fanu's Carmilla (1871-2) or Bram Stoker's Dracula (1897), the vampire is invested with specific religious, cultural, class-related, and racial content. To look first at religion, in these British stories, the vampire typically comes from, or represents, a non-normative form of religion and the figure has been linked to the biblical character of the Wandering Jew and to Jewry in general as discussed by Judith Halberstam, ${ }^{5}$ to Catholicism as explored by Patrick O'Malley, ${ }^{6}$ and even to Islam through Dracula's location on the border between the former Ottoman empire and Christian Europe. The vampire is furthermore fought with the aid of Christian symbols and artefacts: the cross, communion wafers, holy water. The point here is, of course, that these early gothic tales are also narratives of how the religious and cultural Other that the Vampire represents spreads disease. In the case of Dracula, the eponymous vampire is poised to trigger a pandemic of apocalyptic proportion. By satiating his "lust for blood" among the "teeming millions" of London he will "create a new and ever-widening circle of semi-demons to batten on the helpless". Through his diseased and infectious blood, Dracula is able to spread his own form of abject religious, cultural and, indeed, biological liminality, producing an essentially diseased "semi-demon". The social order he imagines does not come about, but it does look back in time, towards a feudal order where he remains lord of the castle, and his minions exist only to do his bidding.

11 The modern, pandemic horror narrative is arguably often involved in the same kind of discursive project. As discussed above, contemporary Gothic horror cinema accelerates the horror element always associated with narratives of pandemics by casting the carrier not as a passive host, but as an aggressive agent of the disease. Thus, the carrier of the viral pandemic is still often the vampire or this creature's proletarian evolution: the zombie. The zombie is like the vampire in that it feeds off the same human race to which it used to belong. The zombie is different from the vampire though, as Kyle William Bishop has observed, ${ }^{8}$ in that it seems to have lost not only rationality but also all desire in middle class comforts or trappings. ${ }^{9}$ As I will argue, the modern zombie looks, and 
often behaves, like the nightmarish, middle-class vision of the homeless, impoverished migrant: poorly dressed, dirty, irrational, needy, potentially violent especially in large numbers, incomprehensible, diseased and infectious. Thus, the most frightening thing about this being is that the middle-class consumer may be forced to join it.

British and US popular culture still often makes use of the basic model provided by Dracula, where the pandemic is seen to arise from a liminal Eastern space, and carried by an agent of this space. In the typical Anglo narrative, this agent then invades the West and proceeds to infect its unsuspecting and innocent citizens. As Johan Höglund has argued in The American Imperial Gothic (2014), much of US horror and Gothic reproduce in Gothic narrative the tension between white Anglo Empire and the various categories that are seen to challenge the hegemony of this entity. In the post-9/11 era, the image of the "Islamic terrorist" has, not surprisingly, been central to both Gothic and non-Gothic representations of the global pandemic. As an example from non-Gothic writing, Michael T. Osterholm argues in his alarmist non-fiction book Living Terrors: What America Needs to Know to Survive the Coming Bioterrorist Catastrophe, that "I do not believe it is a question of whether a lone terrorist or terrorist group will use infectious disease agents to kill unsuspecting citizens; I'm convinced it's really just a question of when and where". ${ }^{10}$

At the time of writing, Ostermholm's prediction has not been realized, but similar fears have taken form in best-selling novels such as Terry Hayes' I am Pilgrim (2013) or in Jonathan Maberry's Patient Zero (2009). Both texts describe how militant jihadists engineer vastly destructive pandemics and attempt to release them into the West in an effort to destroy its hegemonic position and to thus further their own religious agendas. In the case of Patient Zero, the pandemic produces a zombie-like carrier who aggressively spreads the disease.

The plethora of such writing has garnered significant scholarly attention. Mark Dery is one of many to have observed that "visions of a zombie apocalypse look a lot like the troubled dreams of an age of terrorism, avian flu, and H1N1, when viruses leap the species barrier and spread, via jet travel, into global pandemics seemingly overnight". ${ }^{11}$ In other words, in the "age of terrorism", mortal pandemics such as avian flu, H1N1, and Ebola merge effectively with terrorism in the figure of the zombie. This happens frequently not just in the novel but, even more so, in horror cinema. There also do battles between the US military and representatives of a Middle East imagined as diseased play out. In Ozombie (2012), Usama bin Laden have risen from the undead and now walk Afghanistan where US Special forces soldiers must combat him and his minions. In the brief prologue of Zack Snyder's significantly more financially successful remake of Dawn of the Dead (2004), the connection between the violent zombie outbreak and the Middle East is more subtle. The very first image of this opening is of trees moved by the wind before a blue sky. In the next instance, the name of the production company, Universal Pictures, is shown in red against a black background. The name liquefies and spills to the right, like blood, before the third image of the film appears: a mosque where a large number of worshippers have gathered and bend over in prayer. 


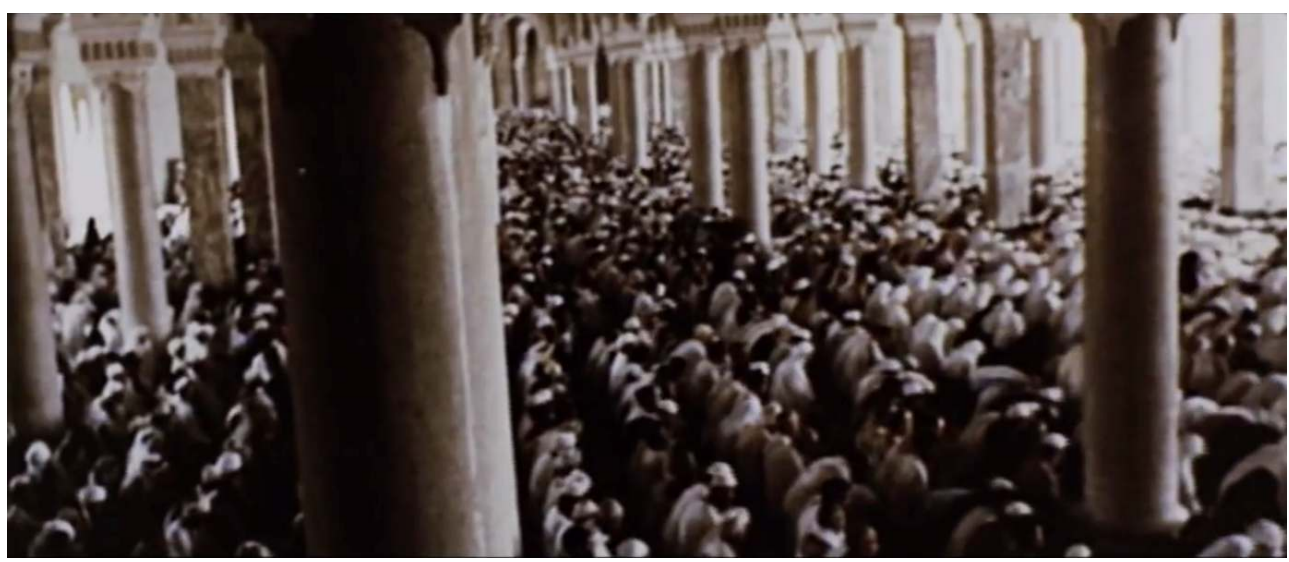

Caption: People praying in a mosque as shown in the opening sequence of Dawn of the Dead (2004).

This brief scene is never commented on within the film and its connection to the violence that follows is indirect. It shows no conflict or unrest, only a second of recorded worship. Even so, it arguably organises the audience's understanding of the horrifically violent pandemic depicted in the film that follows. As the title sequence rolls on, seemingly documentary photography shows civil unrest while other, clearly staged, images depict a White House press conference breaking down, close ups of snarling, grisly faces, images of blood cells trembling and splitting apart under the lens of a microscope, and, increasingly, of modern society collapsing. Set before these images, and before the violence of the main narrative, the first scene of the mosque merges with the short-cut origin story of the pandemic that the prologue tells. In other words, brief second of prayer that is shown before the barrage of violence, clearly works to disturb the audience, and to inform the images of violence that follows.

After the initial and disturbing prelude, Dawn of the Dead revolves around a group of Americans who struggle against a tide of undead zombies. The actual movie begins with a young middle-class couple in suburban Milwaukee who have eschewed television in favour of "date night" or an evening of scheduled love-making in the middle of a busy working week. Because of this they miss an emergency news bulletin and find out about the zombie pandemic when, early in the morning, the neighbour's pre-adolescent girl enters appears in the door to the bedroom, her face in shadow. For a brief moment, the scene is thoroughly recognizable to any nuclear family, where a child hovers on the doorstep to the sanctuary that the parents' bedroom constitutes. Then, the girl steps into the light, her face a bloodied mess, and proceeds to attack the young man. Soon, he too is infected and his wife barely escapes into the bathroom and out the window into a world that is utterly lost to chaos. The suburban community has been transformed into burning and confusing territory of random carnage.

The wife drives through the wreckage of her neighbourhood as it fall apart around her, and soon ends up at a shopping mall where she meets other survivors besieged by the undead. Stripped of their privileges, the protagonists rely on the mall's security infrastructure provides temporary respite. As in Train to Busan, many of the survivors were once middle class, but there is no privilege to be had in the post-pandemic world that the film is set in. The only meaningful preoccupation is the maintenance of the borders that separate the still uninfected from the violent, diseased undead. Indeed, in global pandemic cinema, the construction of borders is always central. The most crucial such border is that of the body. In pandemic horror cinema, this specific border is not crossed 
quietly, through the air or through the contact with the diseased skin of the Other, but through a bite that breaks the skin and mingles the saliva of the zombie with the blood of the victim.

The border that the body constitutes is protected, especially in US pandemic cinema, partly by the borders that vast, physical walls constitute, but equally by constant gun violence. Such violence and such walls play an important part towards the end of Francis Lawrence's remake of I am Legend (2007), where a vampire virus has transformed New York and the world into an uncanny wilderness. Within this wilderness, virologist and US Army Colonel Robert Neville struggles to produce the cure that is, in the film's last scene, delivered to a gigantic, walled in compound within which American heartland society appears to have survived.

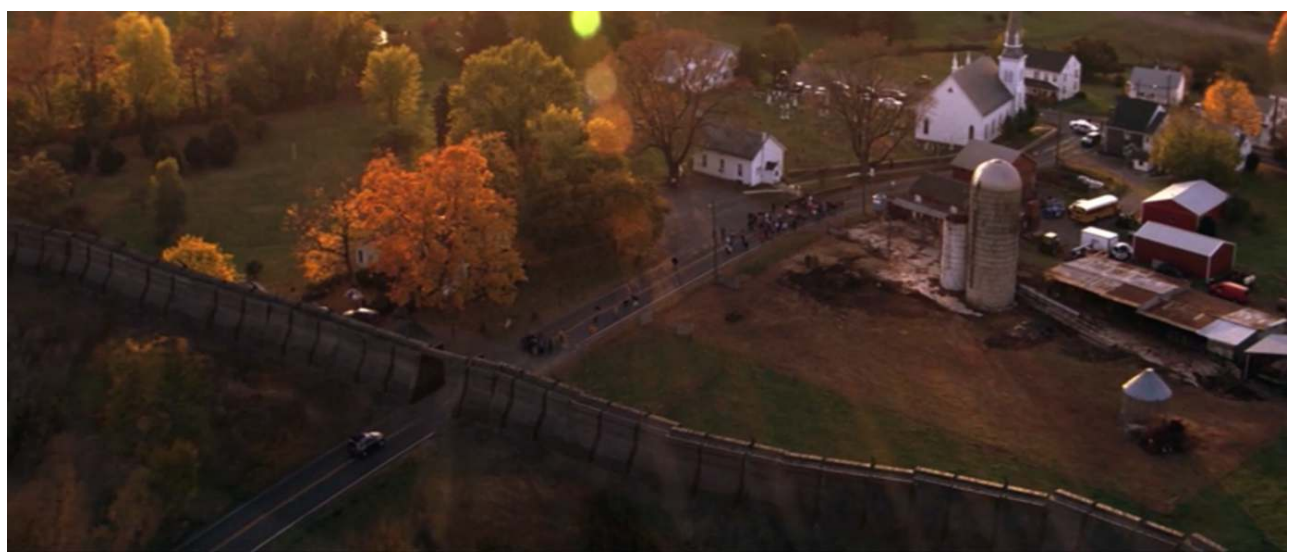

Caption: Part of the wall enclosing a US, post-epidemic colony in I am Legend (2007). Note the centrality of the Christian church in the community.

19 Similarly, in World War Z (2013), another big-budget Hollywood film that also belongs to the pandemic horror genre, Jerusalem has managed to survive a global zombie outbreak thanks to already existing walls and thanks to their ever-vigilant army. Outside the wall, tattered zombies roam the streets in large groups. Inside, members of the Jewish community survive side by side with members of the Islamic. In the face of the zombie pandemic, the film imagines political and religious differences to have disappeared.

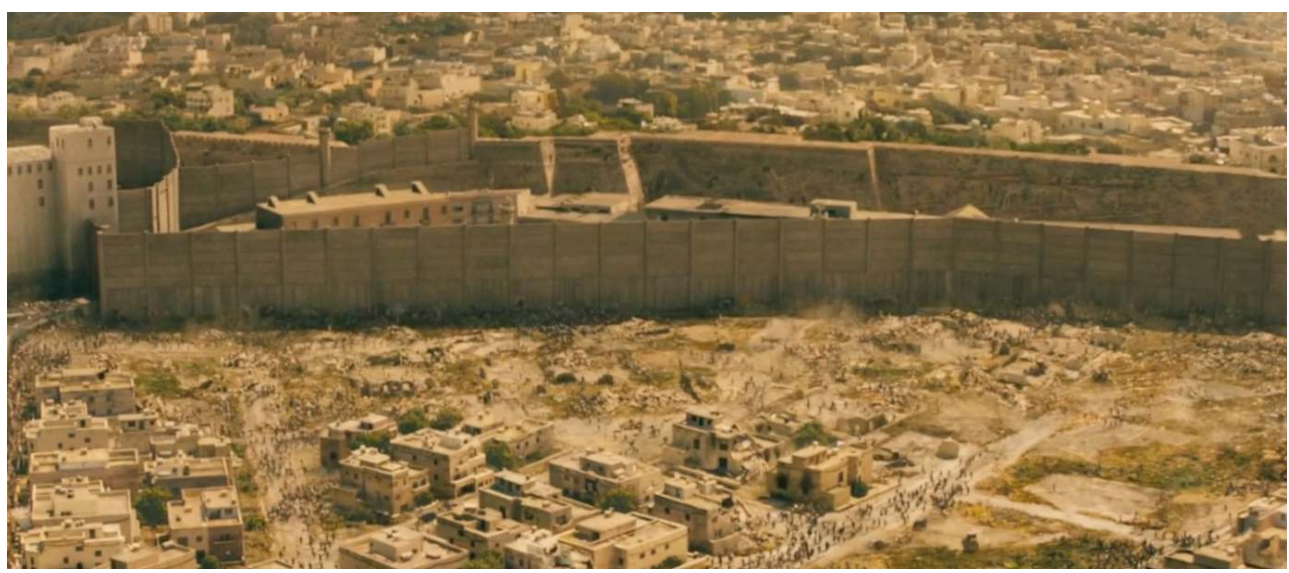

Caption: The walled-in part of Jerusalem where uninfected humans can hide from the infected masses outside.

Large physical walls are central to US pandemic horror film, but they do not always serve to protect the people inside them. Horror films demand that borders are breached and in 
World War Z, even the massive walls and tremendous fire power of the Israeli army cannot keep the zombies out. Even so, the only hope these films present is a thoroughly militarized modernity; a society where everyone is armed and vigilant, their eyes always scanning the large physical borders that separate the uninfected confines of the community from the savage world outside it. By casting the subaltern as a supremely aggressive, possibly undead, cannibal, great violence against this figure becomes not only legitimate: it is a necessity for continued survival. Thus, the central figure in US pandemic horror film is often not the scientist who is trying to find a cure, but the armed soldier or survivalist who is killing the infected off. Thus, the solution to global health in this type of cinema, or at least to the immediate survival of humanity, is military. The solution is a war fought by posses of armed white men, by platoons of Marines, by special forces soldiers gunning down a migratory flood of supremely aggressive beings trying to scale the wall that keeps them from invading what is left of organised society.

\section{Pandemic Horror Film against the Dominant Strain}

21 The pandemic horror narrative produced, primarily, in the US has had a tremendous impact on global pandemic horror cinema. As discussed above, a great portion of these narratives are firmly conservative and tie the different anxieties that traverse the US to images of societal collapse cast as zombie apocalypse, and suggest that the only way to survive is to organise society according to strictly militarized mores. However, there is also a US tradition that complicates this dominant and normative narrative. Alternative, counter-hegemonic narratives appear in the 1950s and 60s, and become legion in the 1970s. These are often low-budget productions, but they have had considerable impact on the pandemic narrative inside and outside Anglo borders. An important text here is Richard Matheson's original I am Legend, which tells a story very different from the 2007 film. As in the original, the protagonist believes himself to be the only human being to have survived a global pandemic that has transformed everyone else to vampires. By night, he holds out against the onslaught of the vampires outside. By day, he seeks them out to destroy their then dormant bodies. Not until the ending of the novel does he begin to understand that vampire society is now the new normal, and that he is, in their eyes, a lone and murderous monster. This reversal of normativity also guides the production of George Romero's Night of the Living Dead (1968) and its sequel Dawn of the Dead (1978), the original of Snyder's 2004 remake discussed above. Here, the zombie pandemic is not understood to have travelled from a liminal East. Instead, in Night of the Living Dead, the protagonist is a black man who is trying to shield himself and a group of cowardly white people from a host of similarly white, middle-class zombies who, relentless and cannibalistic, have risen from their graves. Somehow surviving the terrible night, the protagonist walks into the daylight only to get shot by a white posse and then thrown haphazardly onto a gigantic pyre as the end credits begin to roll.

If global pandemic horror cinema looks to the US for inspiration, this cultural context allows for a number of different positions along an ideological strata that stretches between two extremes. On the one side of this strata, Otherness is seen to emanate from a still orientalised and Islamic East, and to result in the collapse of a white, middle-class modernity seen as absolutely central to Western selfhood. On the other side, it is Western society itself, the reliance on white masculinity, the uncritical belief in modernity, that is the real horror that produces the illness. 

of the late director's other oeuvre. It also surfaces in interesting ways in Train to Busan. To return to this film, the young woman transformed into voracious cannibal begins to spread the illness she carries to other passengers, changing them into similarly aggressive beings. Soon, the few uninfected protagonists are collected in one of the front sections of the train. They manage to communicate with the driver of the locomotive car and are told that the train, and all of South Korea, is caught up in a nation-wide crisis of unknown proportions. What remains of organized, modern society attempts to engineer their rescue from the train, and they are told that the army will be waiting to receive them further down the line. However, when they pull into the assigned station and get out of the train, the station is eerily quiet. They move down a set of escalators and finally make contact with the waiting military, only to find that they too have been transformed. In the scene that ensues, a hoard of bloodied, frenzied young men in uniform storm the people who have exited the train, biting, killing and transforming them. back on board, but modernity, even in the shape of this technologically advanced form of transportation, does not offer any real or lasting security. Similarly, the military provides no protection. When they finally appear in the movie, they pose the largest threat so far, ruthlessly decimating the few survivors. They, and the context to which they belong, offer no protection from a disaster that, the audience is informed, was in fact produced by capitalist modernity itself. The absent father, an investment manager, has helped fund and also put pressure on, the biotech companies that have developed and released the virus. In this way, Train to Busan upends the logic of the conservative pandemic narrative. Whether we understand modernity as the confluence of capitalism with technology that enabled, and was enabled by, colonialism, as suggested by Gurminder Bhambra in Rethinking Modernity: Postcolonialism and the Sociological Imagination, ${ }^{12}$ or simply as a society organised around industry and rational thinking, the pandemic has in fact been engineered within and by this entity. A warlike modernity is not what shelters the human in these narratives, it is what has produced the plague that turns people into ravenous carnivores.

The same ideologically disruptive model characterizes a number of other zombie films, including the six-movie Resident Evil franchise (2002-2016), where a multi-national pharmaceutical company known as the Umbrella Corporation has engineered a virus that has thrown the world into chaos. Similar stories play out in Danny Boyle's 28 Days Later (2002), in novels such as those of Justin Cronin's The Passage trilogy and in several other narratives. What complicates the critique of capitalist modernity that these texts arguably launch is the fact that the only imaginable resolution is still military. The Resident Evil franchise may describe capitalism as the culprit and the agent of illness, but the only solution to managing the multitude of disenfranchised diseased is still violence and the films revolve around scenes where super-skilled human soldiers combat hordes of infected and mutated beings. In the post-pandemic, post-apocalyptic societies these narratives imagine, the choice facing the protagonists is not between a sheltered middleclass existence and the abject poverty of zombiefied existence, but between this existence and the life of an ever vigilant soldier protecting the barriers of a militarized micro-state. 


\section{Eat the Rich}

Although pandemic horror cinema sometime identifies capitalist modernity as the source of the violent plague that transforms society, it typically cannot imagine an alternative political organisation that does not rely on the dichotomies between modern and primitive, rich and poor, armed and disarmed, and healthy and diseased. The border is still the paradigm, and this border recalls a long series of images from the Western past and present: the walled-in forts of the US nineteenth-century frontier landscape built to keep settlers safe from the indigenous populations outside, or the Trump's administration's promise to "build the wall" between the US and its southern border in an effort to revive a strong, independent, white and middle class America. It similarly manifests in European political discourse on refugee migration from northern Africa and the Middle East into Europe. Here also are a number of different borders being erected and fortified. ${ }^{13}$ Thus, despite gestures towards a desacralisation of modernity and middleclass existence, horror pandemic cinema does not offer any systematic critique of capitalism, modernity, or militarism. The genre directs the viewer's attention towards a protagonist that is almost invariably a white, middle class citizen faced with the imminent threat to be eaten and infected. Regardless of whether the infection was engineered by terrorists from the Middle East or by the modern state itself, this protagonist must grab a gun and help cull the diseased multitude that presses against the quickly erected barriers that now constitute the limits of civilisation. In the future of the zombie pandemic, the protagonist must always be, or become, a soldier standing vigilant on the wall that separates the remains of civilisation from the voracious and barbaric multitude below.

However, while this basic analysis does say something about how pandemic horror cinema participates in the conversation on the imagined diseases of the Other, it does not fully account for the contribution that the genre actually makes. To fully grasp this, it is necessary to avert one's gaze from the protagonist that arguably constitutes the focus of attention of the audience, to the infected that demand even more constant attention from the protagonist. While the pandemic drastically transforms the living conditions of the middle class in horror film, those struck by the plague undergo even more dramatic change. As discussed above, the zombie is strongly connected to the image of the impoverished subaltern. In what is usually referred to as the first zombie film, White Zombie (1932), virtually all zombies are black, sedate slave labour and while the audience is encouraged to focus their attention to the white American female who is also transformed into a zombie, it is the disposable black zombie slaves, who topple to their death from a cliff at the end of the movie, that deserve it. As Aalya Ahmad has observed, the zombies that beset western society in the zombie pandemic film is 'redolent of the subaltern'. ${ }^{14}$ Looking away from the white protagonist and instead focusing on the zombie as subaltern poor, enables a very different understanding of what these films do.

To understand the zombie as subaltern entails a combined focus on race and class. The term subaltern, of course, was coined by Antonio Gramsci and refers in his writing to the disenfranchised poor barred from the established institutions of (Italian) society by the fascist government. ${ }^{15}$ In postcolonial or subaltern studies, the concept has been used to describe those denied access to the power structure of the colonial metropole as it operates both in the centre and the margin. This subaltern is a person denied political

Transtext(e)s Transcultures 跨文本跨文化, 12 | 2017 
representation, economic independence, social and medial security and even the right to speak as in Gayatri Spivak's influential and often referenced essay "Can the Subaltern Speak" ${ }^{16}$ The zombie quite easily fits all of these categories. Reduced to an object (no longer a he or a she), it has lost all claims to citizenship and can be killed off with impunity (although not always without emotional turmoil). In the television series The Walking Dead, the zombieified human and former citizen wanders aimlessly along defunct suburban street in images that strongly recall the urban poor of post-depression US society. In movies such as World War Z, their frantic scaling of borders much more strongly recall the refugee migrants desperate attempt to flee war and social turmoil by crossing national borders.

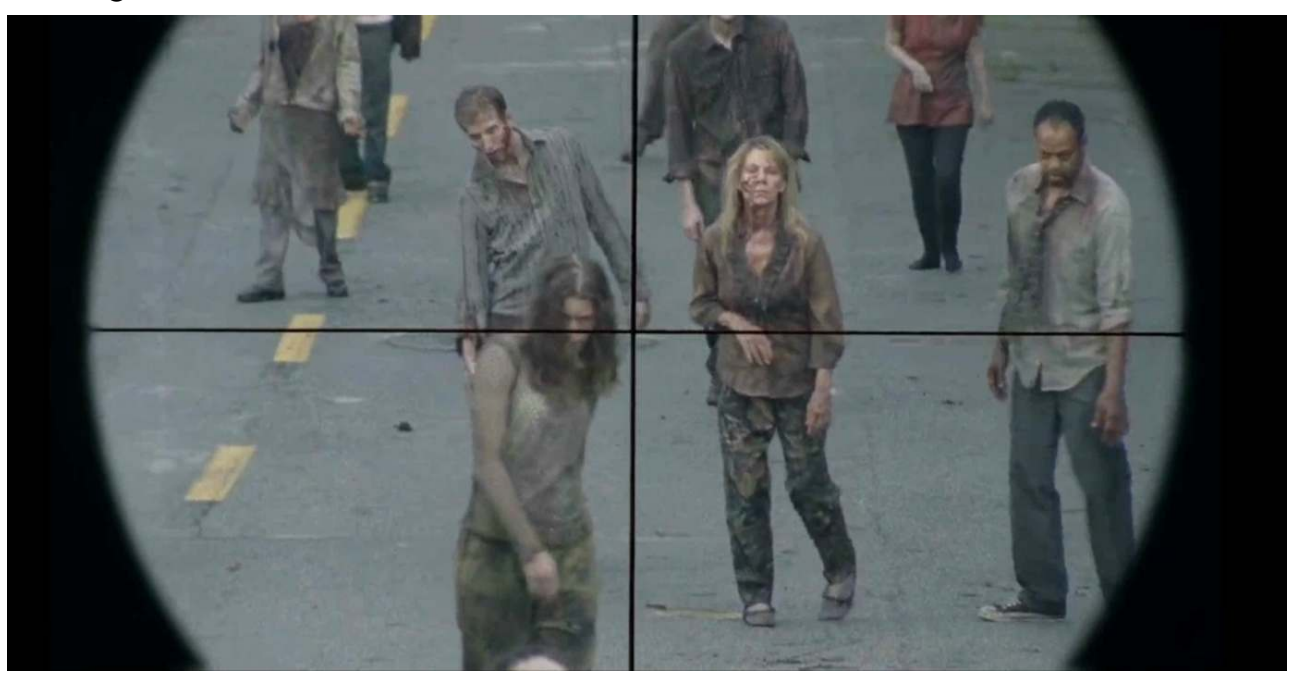

Caption: The undead zombies of The Walking Dead may still wear the tattered clothing that mark them as middle class, but their emaciated and dirty appearances strongly recall images of the urban homeless.

While post-communist global society rarely encourages an understanding of the world's poor population as potentially powerful or even worthy of consideration, pandemic horror cinema arguably invests the subaltern with tremendous agency. The imagined disease that the poor as Other suffer from is central here. It is the disease that fuels the displaced revolution that takes place in pandemic horror cinema. It is, paradoxically, through illness and even death, that the subaltern can enact direct political transformation. The pandemic makes it possible for them to sever their ties to modernity. They are no longer in need of its comforts or protection. Similarly, they can now refuse to help reproduce it. The former rulers of modernity, the middle class for which they toiled, have become their sustenance. The subaltern now eat the rich.

Again, this is hardly a sustained or useful critique of the present social order or of the current geopolitical situation. However, it does provide an understanding of how western and global culture imagines Otherness, disease and their connection to social and global relations. Pandemic horror cinema strongly suggests that what truly frightens the global, middle class audience for which these movies are produced is, ultimately, the prospect that they may be stripped of their privileges and made to join, as if struck by a chronic and terribly dilapidating disease, the ranks of the global poor. As such, they will be forced, for the rest of their miserable existence, to roam unsheltered in search of the sustenance constituted by their own class. This anxiety is described differently in different examples of the genre, but it is remarkably resilient and, like the pandemics they describe, these films move easily across national and linguistic borders. Through 
web-based video and television companies such as Netflix and Amazon television, they reach a wide audience. Through piracy sites and fan subs, they reach even further. In this way, these films can be said to not only speak about pandemics; through their global spread, they also constitute a form of discursive pandemics in themselves.

\section{NOTES}

1. Adolphe Thiers, The History of the French Revolution. Trans Frederick Shoberl, $3^{\text {rd }}$ ed. Philadelphia, A Hart, Late Carey \& Hart, 1850, p. 359.

2. Rob Nixon, Slow Violence and the Environmentalism of the Poor, Cambridge MA, Harvard UP, 2011.

3. Dipesh Chakrabarty, "Humanities in the Anthropocene: The Crisis of an Enduring Kantian Fable”, New Literary History, vol. 47, no. 2 \& 3, Spring \& Summer 2016, p. 377-397.

4. David Nirenberg, Communities of Violence: Persecution of Minorities in the Middle Ages, Princeton NJ, Princeton UP, 1998, p. 231-2.

5. Judith Halberstam, “Technologies of Monstrosity: Bram Stoker's "Dracula"”. Victorian Studies, Vol. 36, No. 3, Spring, 1993, p. 333-352.

6. Patrick R O'Malley, Catholicism, Sexual Deviance, and Victorian Gothic Culture, Cambridge, Cambridge University Press, 2006, p. 146-50.

7. Bram Stoker, Dracula. New York, Grosset \& Dunlap, 1897, p. 48-9.

8. Kyle William Bishop, The Rise and Fall (and Rise) of the Walking Dead in Popular Culture, Jefferson NC, McFarland \& Company, 2010.

9. There are a few exceptions from this rule: most importantly iZombie (2015-) and the Santa Clarita Diet (2017-) where the female protagonists transform into zombies but remain rational and carry on their middle class lives.

10. Michael T. Osterholm, Living Terrors: What America Needs to Know to Survive the Coming Bioterrorist Catastrophe, New York NY, Dell Publishing, 2000, p. xvii.

11. Mark Dery I Must Not Think Bad Thoughts: Drive-By Essays on American Dread, American Dreams, Minneapolis: University of Minnesota Press, 2012, p. 11.

12. Gurminder Bhambra, Rethinking Modernity: Postcolonialism and the Sociological Imagination, Basingstoke, Palgrave MacMillan, 2007.

13. See Kim Moody The Neoliberal Remaking of the Working Class in The SAGE Handbook of Neoliberalism, eds Damien Cahill, Melinda Cooper, Martin Konings, and David Primrose, Los Angeles CA, SAGE, 2018, p. 403.

14. Aalya Ahmad «Gray Is the New Black: Race, Class, and Zombies » in Generation Zombie: Essays on the Living Dead in Modern Culture, Jefferson NC, McFarland \& Company, 2011, p. 130.

15. Antonio Gramsci, Selections from the Prison Notebooks, ed. and transl. Quintin Hoare and Geoffrey Nowell Smith, London, Lawrence and Wishart, 1971.

16. Spivak, Gayatri Chakravorty, "Can the Subaltern Speak?" in Marxism and the Interpretation of Culture, ed. Cary Nelson \& Lawrence Grossberg, Basingstoke: Macmillan Education, 1988, p. 271-313. 


\section{ABSTRACTS}

This essay posits that pandemic horror cinema speeds up the slow violence of the pandemic so that political stakes become apparent. Thus, pandemic horror cinema enables an eloquent conversation on the relation between the imagined diseases of the Other and modernity as an engine of middle-class preservation. The essay traces the tradition of the gothic and horror pandemic narrative from its nineteenth-century origins to the present moment in time when it has proliferated into a number of different nations, languages and ideological positions. The article then explores these positions through a discussion of the films Dawn of the Dead (2004), I am Legend (2007), World War Z (2013), and Train to Busan (2016). Focussing on religion, race, ethnicity, and class, the essay describes how the pandemic horror cinema helps project different understandings of self and Other through the image of violent pandemic disease.

\section{AUTHOR}

\section{JOHAN HÖGLUND}

Johan Höglund is associate professor of English at Linnaeus University and Director of the Linnaeus University Centre for Concurrences in Colonial and Postcolonial Studies. He has published extensively on the relationship between imperialism and popular culture as it manifests in a number of different contexts, including the late-Victorian era, the long history of US global expansion and decline, and the often unrecognized era of Nordic colonialism. He is the author of numerous scholarly articles, of the monograph The American Imperial Gothic: Popular Culture, Empire, Violence (2014), and the co-editor of B-Movie Gothic: International Perspectives (2018), Animal Horror Cinema: Genre, History and Criticism (2015), and Transnational and Postcolonial Vampires (2012). 